\title{
Contribution of dissolved organic matter to submicron water-soluble organic aerosols in the marine boundary layer over the eastern equatorial Pacific
}

\author{
Yuzo Miyazaki $^{1}$, Sean Coburn ${ }^{2,3}$, Kaori Ono ${ }^{1}$, David T. Ho ${ }^{4}$, R. Bradley Pierce ${ }^{5}$, Kimitaka Kawamura ${ }^{1}$, and \\ Rainer Volkamer ${ }^{2,3}$ \\ ${ }^{1}$ Institute of Low Temperature Science, Hokkaido University, Sapporo, 060-0819, Japan \\ ${ }^{2}$ Department of Chemistry \& Biochemistry, University of Colorado, Boulder, CO 80309-0215, USA \\ ${ }^{3}$ Cooperative Institute for Research in Environmental Sciences (CIRES), University of Colorado, Boulder, CO \\ 80309-0215, USA \\ ${ }^{4}$ Department of Oceanography, University of Hawaii, Honolulu, HI 96822, USA \\ ${ }^{5}$ National Oceanic and Atmospheric Administration (NOAA), The National Environmental Satellite, Data, \\ and Information Service (NESDIS), Madison, WI 53706, USA
}

Correspondence to: Yuzo Miyazaki (yuzom@lowtem.hokudai.ac.jp)

Received: 23 February 2016 - Published in Atmos. Chem. Phys. Discuss.: 14 March 2016

Revised: 26 May 2016 - Accepted: 5 June 2016 - Published: 23 June 2016

\begin{abstract}
Stable carbon isotopic compositions of watersoluble organic carbon (WSOC) and organic molecular markers were measured to investigate the relative contributions of the sea surface sources to the water-soluble fraction of submicron organic aerosols collected over the eastern equatorial Pacific during the Tropical Ocean tRoposphere Exchange of Reactive halogens and Oxygenated VOCs (TORERO)/KA-12-01 cruise. On average, the watersoluble organic fraction of the total carbon (TC) mass in submicron aerosols was $\sim 30-35 \%$ in the oceans with the low chlorophyll $a(\mathrm{Chl} a$ ) concentrations, whereas it was $\sim 60 \%$ in the high-Chl $a$ regions. The average stable carbon isotope ratio of WSOC $\left(\delta^{13} \mathrm{C}_{\mathrm{WSOC}}\right)$ was $-19.8 \pm 2.0 \%$, which was systematically higher than that of $\mathrm{TC}\left(\delta^{13} \mathrm{C}_{\mathrm{TC}}\right)$ $(-21.8 \pm 1.4 \%)$. We found that in the oceans with both high and low Chl $a$ concentrations the $\delta^{13} \mathrm{C}_{\mathrm{WSOC}}$ was close to the typical values of $\delta^{13} \mathrm{C}$ for dissolved organic carbon (DOC), ranging from -22 to $-20 \%$ in surface seawater of the tropical Pacific Ocean. This suggests an enrichment of marine biological products in WSOC aerosols in the study region regardless of the oceanic area. In particular, enhanced levels of WSOC and biogenic organic marker compounds together with high values of WSOC / TC $(\sim 60 \%)$ and $\delta^{13} \mathrm{C}_{\mathrm{WSOC}}$ were observed over upwelling areas
\end{abstract}

and phytoplankton blooms, which was attributed to planktonic tissues being more enriched in $\delta^{13} \mathrm{C}$. The $\delta^{13} \mathrm{C}$ analysis estimated that, on average, marine sources contribute $\sim 90 \pm 25 \%$ of the aerosol carbon, indicating the predominance of marine-derived carbon in the submicron WSOC. This conclusion is supported by Lagrangian trajectory analysis, which suggests that the majority of the sampling points on the ship had been exposed to marine boundary layer (MBL) air for more than $80 \%$ of the time during the previous 7 days. The combined analysis of the $\delta^{13} \mathrm{C}$ and monosaccharides, such as glucose and fructose, demonstrated that DOC concentration was closely correlated with the concentration levels of submicron WSOC across the study region regardless of the oceanic area. The result implies that DOC may characterize background organic aerosols in the MBL over the study region.

\section{Introduction}

The ocean surface is a major source of submicron aerosols in both number and mass concentrations (e.g., Spracklen et al., 2008). These aerosols play an important controlling role in the atmospheric radiative budget because they determine the 
number of cloud condensation nuclei $(\mathrm{CCN})$ and ice nuclei (IN), particularly over the remote ocean. In general, organic matter $(\mathrm{OM})$ is concentrated in the sea surface microlayer relative to the bulk seawater. OM is further concentrated in aerosols during the bubble-bursting process, which produces primary submicron sea spray aerosol (SSA) that is enriched in OM (O'Dowd and de Leeuw, 2007). It has been recognized that marine microorganisms play a large role in marine aerosol formation and its composition. Marine-derived submicron organic aerosol (OA) can affect marine aerosol optical depth (AOD) as well as CCN and IN concentrations. Nevertheless there is still uncertainty in the chemical signatures of SSA, leading to uncertainty in determining their climate impact.

The oceanic surface chlorophyll $a(\mathrm{Chl} a)$ concentration has been used as a proxy for marine phytoplankton biomass. However, linear source functions based on Chl $a$ underpredict organic carbon (OC) enrichments for nascent SSA produced from oligotrophic waters and overpredict OC enrichments for nascent SSA produced from highly productive waters (Long et al., 2011). Recent field and laboratory studies suggest that organic enrichment of SSA might be more closely related to the concentration of oceanic dissolved organic carbon (DOC), rather than to the concentration of Chl $a$ in surface seawater (Prather et al., 2013; Quinn et al., 2014).

To assess the impact of marine biological activity on ambient aerosols and the subsequent formation of clouds, it is important to differentiate marine-derived natural aerosols from anthropogenic aerosols over the oceanic regions. For this purpose, methods need to be established to discriminate between ocean- and land-derived aerosols found in marine atmospheres. A method using the isotopic composition of aerosol carbon has been used successfully to determine the contributions of marine and terrestrial sources to aerosol found in the remote marine atmosphere (Chesselet et al., 1981; Cachier et al., 1986; Kawamura et al., 2004; Miyazaki et al., 2011; Ceburnis et al., 2011). The marine-derived OC $\left(\delta^{13} \mathrm{C} \sim-22\right.$ to $\left.-18 \%\right)$ is enriched in ${ }^{13} \mathrm{C}$ relative to terrestrial $\mathrm{C} 3$ vegetation (which uses the Calvin-Benson cycle as a metabolic pathway for carbon fixation in photosynthesis) and fossil fuel $\mathrm{OC}\left(\delta^{13} \mathrm{C} \sim-30\right.$ to $-23 \%$ o for both) (e.g., Fry and Sherr, 1984). Ocean-derived submicron particles contain a large fraction of water-soluble OC (WSOC), which can significantly alter the hygroscopic property of aerosols (Prather et al., 2013) and act as CCN and IN. Only a few studies have used the ${ }^{13} \mathrm{C}$ of WSOC for source apportionment (Fisseha et al., 2009; Kirillova et al., 2010; Miyazaki et al., 2012). The WSOC-specific ${ }^{13} \mathrm{C}$ analysis in combination with organic molecular markers provides robust tools for the source apportionment of WSOC in marine aerosols.

To better characterize submicron OAs in the marine boundary layer (MBL) and differentiate them from those with terrestrial sources, we investigated the stable carbon isotopic signature of WSOC in submicron aerosols collected over the eastern equatorial Pacific. Primary productivity in that oceanic region accounts for $\sim 23 \%$ of the total productivity of the entire Pacific Ocean (Pennington et al., 2006), and the potential of enhanced $\mathrm{OM}$ in the surface microlayer is present. Deng et al. (2014) found that long-chain organic molecules and humic-like substances (HULIS) were prevalent in the marine aerosol sampled in a latitudinal cruise over the eastern Pacific. Here we investigated possible sources of submicron WSOC over the oceanic region by the analysis of WSOC-specific ${ }^{13} \mathrm{C}$ combined with several organic molecular markers, such as monosaccharides (glucose and fructose) and low-molecular-weight (LMW) fatty acids (FAs).

\section{Experimental}

\subsection{Submicron aerosol samplings}

Aerosol samplings were conducted in the MBL on board the National Oceanic and Atmospheric Administration (NOAA) R/V Ka'imimoana during the Tropical Ocean tRoposphere Exchange of Reactive halogens and Oxygenated VOCs (TORERO) field experiment (Coburn et al., 2014; Volkamer et al., 2015). Figure 1 presents the cruise track over the eastern equatorial Pacific between 25 January and 1 March 2012. The cruise originated in Honolulu, Hawaii, and headed to Puntarenas, Costa Rica (KA-12-01), from 157 to $83^{\circ} \mathrm{W}$ longitude and $21^{\circ} \mathrm{N}$ to $8^{\circ} \mathrm{S}$ latitude.

A cascade impactor (CI; Series 230, Tisch Environmental, Cleves, OH, USA) attached to a high-volume air sampler (HVAS; Model 120SL, Kimoto Electric, Osaka, Japan) was used to collect submicron particles (Miyazaki et al., 2012). The sampler was located on the upper deck of the ship. Aerosol samplings were made using quartz fiber filters $(25 \times 20 \mathrm{~cm})$ set on the bottom stage of the impactor at a sampling flow rate of $\sim 1100 \mathrm{~L} \mathrm{~min}^{-1}$. The sampling time for each sample was approximately $24 \mathrm{~h}$. The samples were collected on precombusted $\left(450^{\circ} \mathrm{C}\right.$ for $\left.3 \mathrm{~h}\right)$ quartz filters, and the average total volume of each sample was $1318.7 \mathrm{~m}^{3}$. The collected samples were stored individually in glass jars with a Teflon-lined screw top cap at $-20^{\circ} \mathrm{C}$ prior to analysis. The aerosol data taken during 1-28 February 2012 were used in this study.

To obtain the average size distributions of the WSOC mass, size-segregated aerosol samplings were also performed with an Andersen-type CI running in parallel to the HVAS. The size-segregated aerosol samples were collected on precombusted quartz filters ( $8 \mathrm{~cm}$ ID) every $\sim 3$ days. The sampling was made according to the $50 \%$ equivalent aerodynamic cutoff diameters, with nine stages between 0.39 and $10.0 \mu \mathrm{m}$ (Miyazaki et al., 2010). Ambient air was drawn at a flow rate of $120 \mathrm{~L} \mathrm{~min}^{-1}$ per sample without temperature and humidity control. Other data were also obtained using an in situ ozone $\left(\mathrm{O}_{3}\right)$ monitor, sonic anemometer and $\mathrm{Chl} a$ fluorometer along the cruise track. 

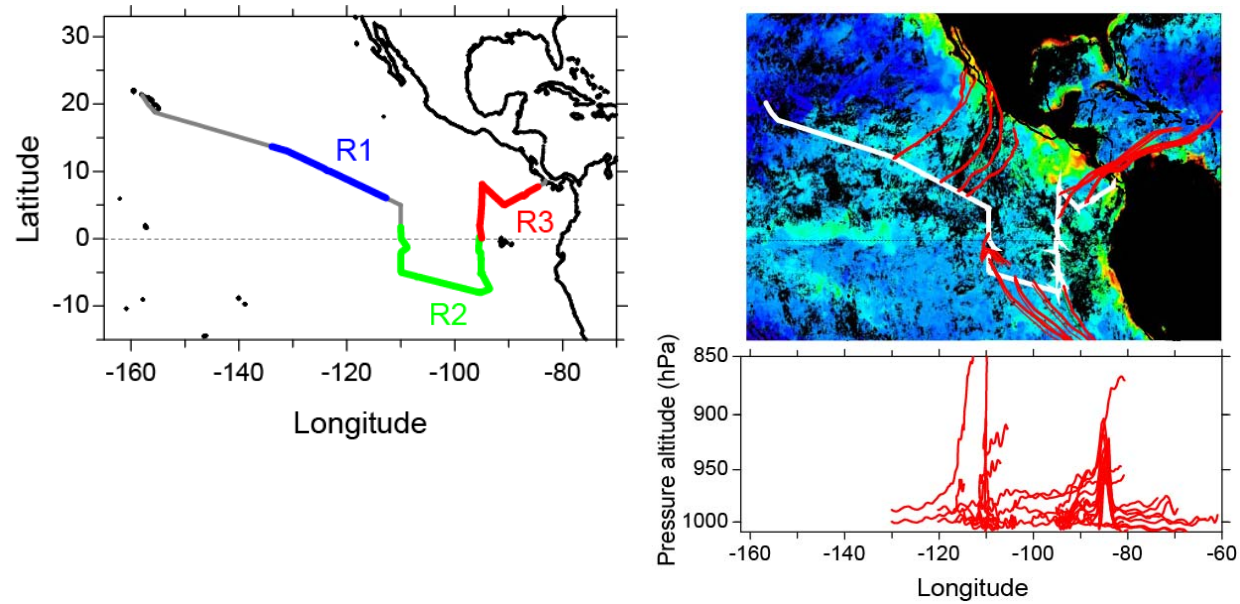

Figure 1. (Left) Cruise track of the National Oceanic and Atmospheric Administration (NOAA) ship Ka'imimoana in the eastern equatorial Pacific between 25 January and 1 March 2012 in three categorized oceanic areas (see text). (Right) Typical 5-day back trajectories (red lines) that started along the cruise track, together with monthly averaged concentrations of chlorophyll $a$ (Chl $a$ ) for February 2012. A vertical cross section of the back trajectories is shown in the right bottom panel.

\subsection{Aerosol chemical analysis}

To determine the WSOC concentration, a portion of each filter sample $\left(19.63 \mathrm{~cm}^{2}\right)$ was extracted with ultrapure water ( $>18 \mathrm{M} \Omega \mathrm{cm}^{-1}$ ) using an ultrasonic bath. The ultrapure water was generated by a Sartorius Stedim Biotech arium pro ultrapure water system (Model 611: Sartorius AG, Goettingen, Germany). The extracts were then filtrated with a disc filter (Millex-GV, $0.22 \mu \mathrm{m}$, Millipore, Billerica, MA, USA), followed by the injection of the DOC in the extracts into a total organic carbon analyzer (Model TOC-Vcsh, Shimadzu, Kyoto, Japan) (Miyazaki et al., 2011). The WSOC value of a field blank corresponded to less than $\sim 13 \%$ of the WSOC concentration of the ambient samples. All WSOC data presented here were corrected against field blanks.

For the determination of $\delta^{13} \mathrm{C}_{\mathrm{WSOC}}$, a filter $\left(14.13 \mathrm{~cm}^{2}\right)$ for each sample was acidified to $\mathrm{pH} 2$ with hydrochloric acid $(\mathrm{HCl})$ to remove inorganic carbon prior to extraction. The decarbonated filter samples were then dried under a nitrogen stream for approximately $2 \mathrm{~h}$. WSOC was extracted from the filters in $20 \mathrm{~mL}$ of the ultrapure water using the method as described above for measuring the WSOC concentration. The extracted samples were concentrated by rotary evaporation, and $40 \mu \mathrm{L}$ of each sample was transferred to be absorbed onto $10 \mathrm{mg}$ of pre-combusted Chromosorb in a pre-cleaned tin cup. The $\delta^{13} \mathrm{C}_{\mathrm{WSOC}}$ was then measured using an elemental analyzer (EA) (NA 1500, Carlo Erba, Milan, Italy) interfaced to an isotope ratio mass spectrometer (IRMS) (Finnigan MAT Delta Plus, Thermo Finnigan, San Jose, CA, USA). The $\delta^{13} \mathrm{C}$ data are reported relative to an established reference of carbon Vienna Pee Dee Belemnite (VPDB). The nitrogen isotope ratio $\left(\delta^{15} \mathrm{~N}\right)$ of water-soluble total nitrogen (WSTN) $\left(\delta^{15} \mathrm{~N}_{\mathrm{WSTN}}\right)$ in aerosols was also measured with basically the same procedure as $\delta^{13} \mathrm{C}_{\mathrm{WSOC}}$, but without any acidification using $\mathrm{HCl}$. In addition, the concentrations of total carbon (TC) and the $\delta^{13} \mathrm{C}$ of $\mathrm{TC}\left(\delta^{13} \mathrm{C}_{\mathrm{TC}}\right)$ (i.e., without water extraction) were also measured with the EA-IRMS for the same aerosol samples (Miyazaki et al., 2010). Further details of the analytical method used for isotopic analysis are given by Miyazaki et al. (2012).

For the determination of inorganic ions, another filter cut was extracted with ultrapure water. The total extract was filtrated through a membrane disc filter, and major anions including methanesulfonic acid (MSA) and cations were determined using an ion chromatograph (Model 761 compact IC; Metrohm, Herisau, Switzerland) (Miyazaki et al., 2011). The MSA value of field blanks corresponded to less than $\sim 12 \%$ of the concentrations of the ambient samples, whereas the blank values of $\mathrm{Na}^{+}, \mathrm{Cl}^{-}$, and $\mathrm{Mg}^{2+}$ were less than $1 \%$ of the ambient concentrations.

For the analysis of possible tracers of marine DOC, a filter portion was extracted with dichloromethane/methanol. The $-\mathrm{COOH}$ and $-\mathrm{OH}$ functional groups in the extracts were reacted with N,O-bis-(trimethylsilyl)trifluoroacetamide (BSTFA) to derive trimethylsilyl (TMS) esters and TMS ethers, respectively. The TMS derivatives were then analyzed for $\alpha$-glucose, $\beta$-glucose, $\alpha$-fructose, $\beta$-fructose, and a homologous series of straight-chain fatty acids $\left(\mathrm{C}_{12}-\mathrm{C}_{19}\right.$ saturated acids) using a capillary gas chromatograph (GC7890, Agilent, Santa Clara, CA, USA) coupled to a mass spectrometer (5973 MSD, Agilent, Santa Clara, CA, USA) (Fu et al., 2011; Miyazaki et al., 2012). The values of a field blank were less than $\sim 24 \%$ of the concentration of these molecular compounds in the ambient samples. 


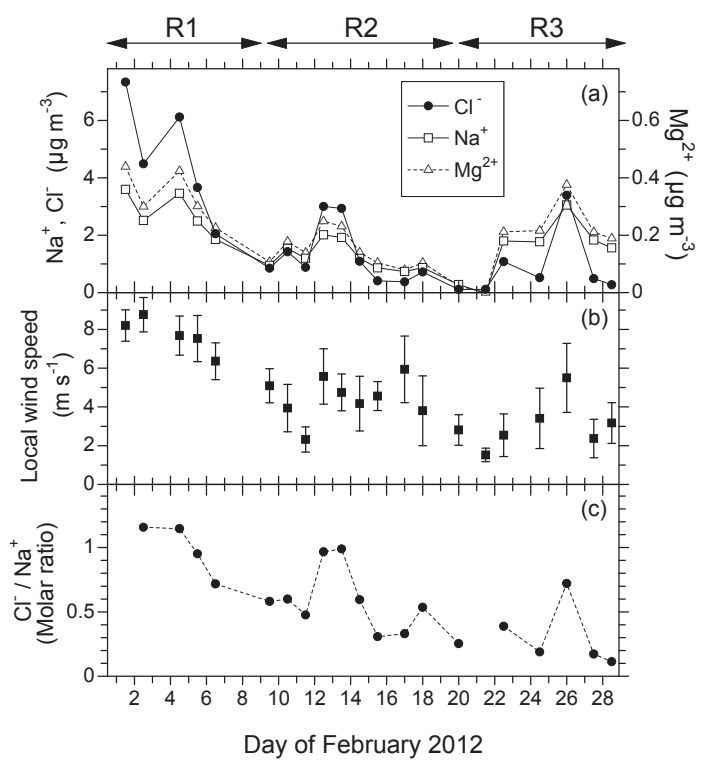

Figure 2. Time series of (a) the concentrations of $\mathrm{Cl}^{-}, \mathrm{Na}^{+}$, and $\mathrm{Mg}^{2+}$; (b) local wind speeds measured on the ship; and (c) the $\mathrm{Cl}^{-} / \mathrm{Na}^{+}$molar ratios. The local wind speed data were merged into the time interval of each filter sampling, and the average values with the SD over each sampling duration are shown. R1, R2, and R3 denote oceanic regions 1,2 , and 3 , respectively, which are defined in the text and shown in Fig. 1.

\subsection{Trajectory analysis}

To investigate air mass histories along the TORERO cruise track, back trajectories were computed with the Real-time Air Quality Modeling System (RAQMS) (Pierce et al., 2007), which calculated chemical and meteorological forecasts. RAQMS has a horizontal resolution of $1^{\circ} \times 1^{\circ}$, with 35 hybrid eta theta vertical levels. Meteorological forecasts are initialized with operational analyses from the National Centers for Environmental Prediction (NCEP) Global Data Assimilation System (GDAS). The RAQMS calculations in conjunction with reverse domain filling (RDF) techniques (Sutton et al., 1994) are based on an analysis of back trajectories initialized along the cruise track. A three-dimensional 7-day back trajectory was calculated using the Langley Trajectory Model (LTM) (Pierce and Fairlie, 1993) and initialized at model hybrid levels along the TORERO cruise tracks.

\section{Results and discussion}

\subsection{Characteristics of sea salt particles}

Figure 2 presents a time series of concentrations of $\mathrm{Na}^{+}$, $\mathrm{Cl}^{-}$, and $\mathrm{Mg}^{2+}$ as tracers of sea spray, together with the daily-averaged local wind speed measured on the ship at each aerosol sampling location. In general, temporal variations of $\mathrm{Na}^{+}, \mathrm{Cl}^{-}$, and $\mathrm{Mg}^{2+}$ in the submicron particles were corre- lated with variation in local wind speeds with $r^{2}$ of $0.41-0.60$ $(n=21)$. This is consistent with the wind-driven production of primary marine aerosol particles, whereas the moderate linear correlation can be explained by a power law relationship between sea spray mass and local wind speed (e.g., Ovadnevaite et al., 2012).

In this study, the aerosol sampling regions were classified into three categories according to the differences in oceanic areas and patterns of backward trajectories (Fig. 1). Region 1 (R1), sampled during the period of 1-7 February 2012, corresponded to open oceans at $5-15^{\circ} \mathrm{N}$ and $112-133^{\circ} \mathrm{W}$. Most of Region 2 (R2) covered the oceanic area in the Southern Hemisphere $\left(8^{\circ} \mathrm{S}-2^{\circ} \mathrm{N}\right.$ and $\left.93-110^{\circ} \mathrm{W}\right)$, where the sampling was conducted during 9-19 February. Region 3 (R3) was close to the coastal region at $0-8^{\circ} \mathrm{N}$ and $84-90^{\circ} \mathrm{W}$, where observations were made during 20-28 February. R1 and R2 are characterized by very low anthropogenic impact on marine ecosystem (Halpern et al., 2008) and represent some of the most pristine ocean environments at tropical latitudes with the low Chl $a$ concentrations (Fig. 1). According to the back trajectories, the air masses sampled in R1 and R3 (i.e., in the Northern Hemisphere) had been transported over the ocean for at least $48 \mathrm{~h}$ prior to aerosol sampling on the ship. The trajectories further indicated that those air masses were not significantly influenced by the land surface for at least 5 days. The air masses sampled in R2 had been transported over the ocean in the Southern Hemisphere for at least 5 days without any significant influence from the land surface or pollution. The relative influence of ocean surface and land on the observed aerosols will be discussed in Sect. 3.3.

In R3, enhanced marine biological activity at the sea surface was observed, with an average Chl $a$ concentration of $0.15 \pm 0.04 \mathrm{mg} \mathrm{m}^{-3}$ (Fig. 1). Because this value is substantially larger than the average concentration in R1 and R2, $\mathrm{R} 3$ is characterized as a high-Chl $a$ region. The enhancement of the Chl $a$ concentration in R3 (up to $0.33 \mathrm{mg} \mathrm{m}^{-3}$ ) could be attributed to surface mixing in the Pacific Eastern Boundary Upwelling System (EBUS) (Rossi et al., 2009) and the coastal region (Pennington et al., 2006). R1 was characterized by high concentrations of sea salt particles with the average molar ratio of chloride to sodium $\left(\mathrm{Cl}^{-} / \mathrm{Na}^{+}\right)$close to unity. This is not necessarily expected in submicron aerosols in the tropical oceanic regions, because rapid acidification of sea salt particles occurs on the timescale of seconds (e.g., Pszenny et al., 2004; Keene et al., 2009). The fact that a depletion of $\mathrm{Cl}^{-}$is apparently less pronounced in R1 indicates that the concentrations of gas species including organic acids (e.g., Laskin et al., 2012) responsible for the $\mathrm{Cl}^{-}$loss were substantially low in $\mathrm{R} 1$. The current results suggest that the submicron particles collected in R1 were more similar to nascent sea spray aerosols compared to those in R2 and R3. The $\mathrm{Cl}^{-} / \mathrm{Na}^{+}$ratio tended to decrease from $\mathrm{R} 1$ (av $1.06 \pm$ 0.23 ) to R2 (av $0.60 \pm 0.24$ ) and R3 (av $0.32 \pm 0.25$ ). In fact, the $\mathrm{Cl}^{-} / \mathrm{Na}^{+}$ratio tended to decrease with increasing sulfate concentration (not shown in the figure), whereas this 


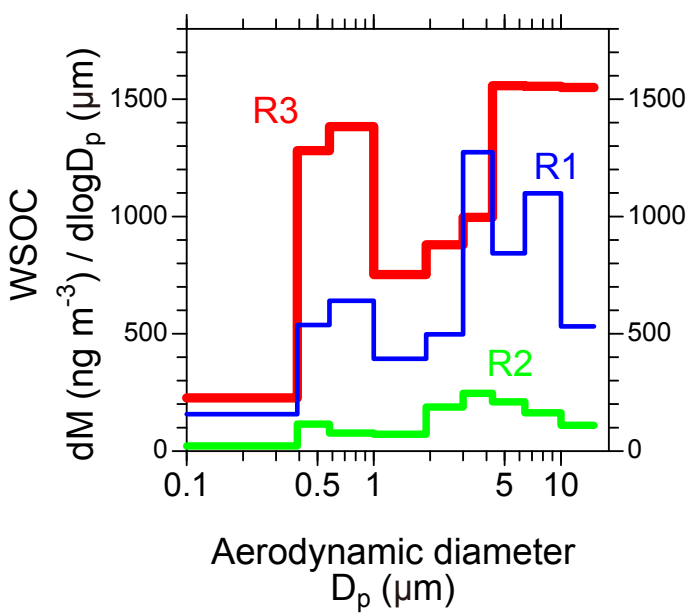

Figure 3. Typical mass size distributions of water-soluble organic carbon (WSOC) in R1, R2, and R3.

trend is not apparent for nitrate. This result suggests the $\mathrm{Cl}^{-}$ depletion by acid substitution in seawater-derived $\mathrm{NaCl}$ and indicates production of more chemically aged particles in $\mathrm{R} 3$ relative to R1 and R2.

\subsection{Size distribution and time series of WSOC and related parameters}

Figure 3 shows the typical mass size distributions of WSOC for each regional category during the TORERO cruise. In general, WSOC displayed a bimodal size distribution, with peaks in the submicron and supermicron particle-size ranges. Bimodal size distributions of WSOC in marine aerosols were also observed in the western North Pacific (Miyazaki et al., 2010), whereas both unimodal and bimodal size distributions of water-soluble organic species were also reported in particles collected at a coastal site facing the eastern North Pacific (Maudlin et al., 2015). The bimodal size observed in this study can be attributed to the difference in the formation processes of WSOC between the two size ranges. The two distinct size modes include (i) direct co-emissions associated with sea salt particles in both size ranges, (ii) aqueous-phase products in the submicron size range, and (iii) partitioning to the surface of coarse particles (i.e., sea salt) and/or heterogeneous reactions in the supermicron size range (Mochida et al., 2002). Although it is difficult to provide a clear explanation by this dataset alone, the observed WSOC size distributions might be explained by some combination of these possible origins and processes. Here we focus on the submicron size of WSOC relevant to its isotope ratios and several chemical tracers.

Figure $4 \mathrm{a}$ shows a time series of the mass concentration of WSOC and its ratio to TC in the submicron particles. In R1 and R2, the WSOC concentrations ranged between 50 and $160 \mathrm{ngC} \mathrm{m}^{-3}$, with averages of $130 \pm 27$ and $85 \pm 24 \mathrm{ngC} \mathrm{m}^{-3}$ for the two regions, respectively. The

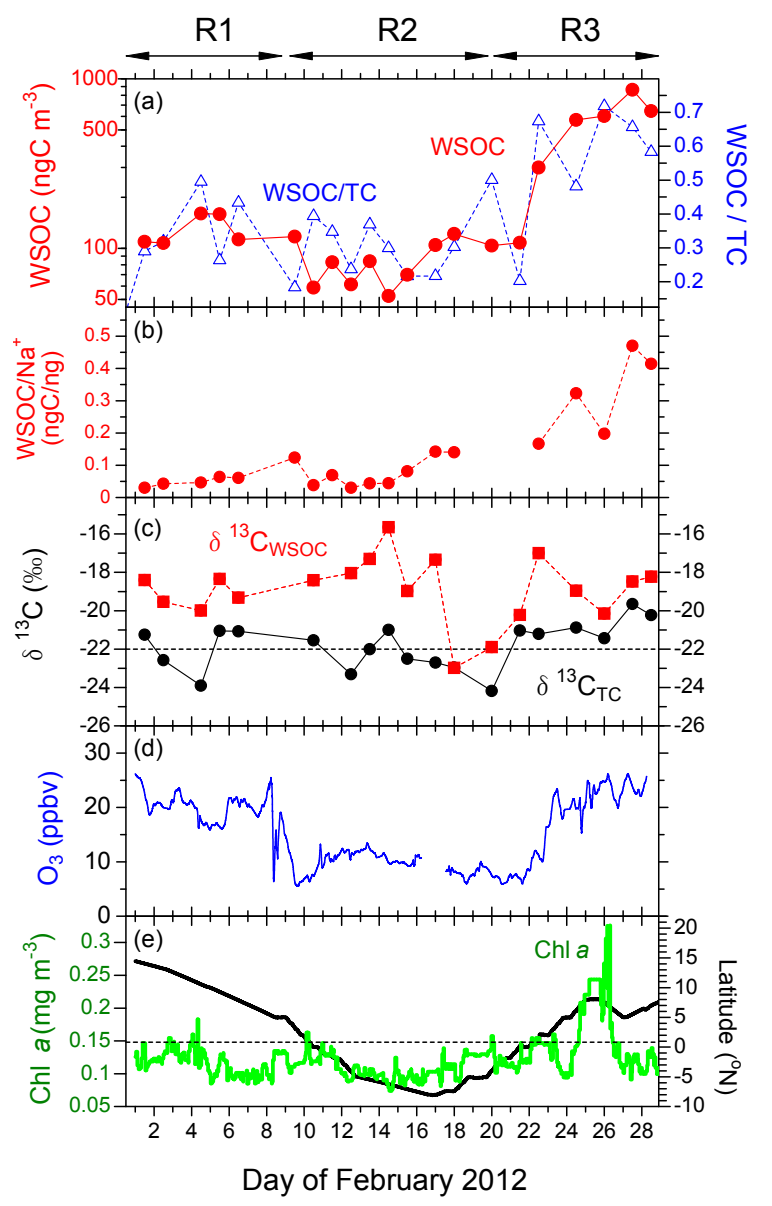

Figure 4. Time series of (a) WSOC, WSOC/total carbon (TC); (b) the mass ratio of WSOC $/ \mathrm{Na}^{+}$; (c) $\delta^{13} \mathrm{C}_{\mathrm{TC}}$ and $\delta^{13} \mathrm{C}_{\mathrm{WSOC}}$; (d) $\mathrm{O}_{3}$ mixing ratios; and (e) in situ $\mathrm{Chl} a$ concentrations in surface seawater, along with the ship's position (latitude). The data for the WSOC $/ \mathrm{Na}^{+}$ratio during 19-21 February are not shown because the $\mathrm{Na}^{+}$concentrations were extremely low $\left(<0.03 \mu \mathrm{g} \mathrm{m}^{-3}\right.$; Fig. 2a), which substantially increased the ratio.

WSOC / TC ratios ranged between 20 and $50 \%$, with averages of $36 \pm 10 \%(\mathrm{R} 1)$ and $31 \pm 10 \%(\mathrm{R} 2)$. Although black carbon $(\mathrm{BC})$ concentration in the $\mathrm{TC}$ fraction was not measured in this study, most of the TC can be attributed to OC under the assumption of extremely low concentrations of $\mathrm{BC}$ $\left(<2 \mathrm{ng} \mathrm{m}^{-3}\right)$ previously observed over this oceanic region (Shank et al., 2012). The lower WSOC / TC ratios in R1 and R2 can be explained by fresh primary marine aerosols enriched in water-insoluble organic carbon (Facchini et al., 2008).

In contrast, both the WSOC concentrations $(515 \pm 268$ $\left.\mathrm{ngC} \mathrm{m}{ }^{-3}\right)$ and the WSOC / TC ratios (62 $\left.\pm 19 \%\right)$ were substantially higher in R3 than those in R1 and R2. Further, the correlation of WSOC with $\mathrm{Na}^{+}$was strongest in $\mathrm{R} 3\left(r^{2}=\right.$ $0.40)$. In the submicron particles, the average WSOC $/ \mathrm{Na}^{+}$ ratio was $0.15 \pm 0.14$ (Fig. 4b), which is within (though near the lower end of) the $\mathrm{OC} / \mathrm{Na}^{+}$ratio range $(0.1-2.0)$ pre- 
Table 1. Average ( \pm standard deviation) and median concentrations and ratios in the different oceanic areas during the Tropical Ocean tRoposphere Exchange of Reactive halogens and Oxygenated VOCs (TORERO) cruise observation. Values in parentheses show those of the 67 th percentile. The precision of each measurement including the blank subtraction is also shown.

\begin{tabular}{|c|c|c|c|c|}
\hline & $\begin{array}{l}\text { R1 } \\
(1-7 \text { Feb 2012) }\end{array}$ & $\begin{array}{l}\text { R2 } \\
(9-19 \text { Feb 2012) }\end{array}$ & $\begin{array}{l}\text { R3 } \\
(20-28 \text { Feb 2012) }\end{array}$ & Precision \\
\hline $\mathrm{Na}^{+}\left(\mu \mathrm{g} \mathrm{m}^{-3}\right)$ & $\begin{array}{l}2.78 \pm 0.73 \\
2.51(3.46 / 2.49)\end{array}$ & $\begin{array}{l}1.25 \pm 0.47 \\
1.19(1.20 / 0.95)\end{array}$ & $\begin{array}{l}2.00 \pm 0.60 \\
1.78(1.83 / 1.77)\end{array}$ & $4 \%$ \\
\hline $\mathrm{Cl}^{-} / \mathrm{Na}^{+}$molar ratio & $\begin{array}{l}1.06 \pm 0.23 \\
1.15(1.16 / 0.95)\end{array}$ & $\begin{array}{l}0.60 \pm 0.24 \\
0.58(0.60 / 0.54)\end{array}$ & $\begin{array}{l}0.32 \pm 0.25 \\
0.22(0.25 / 0.19)\end{array}$ & $6 \%$ \\
\hline WSOC / $\mathrm{Na}^{+}\left(\mathrm{ngC} \mathrm{ng}^{-1}\right)$ & $\begin{array}{l}0.05 \pm 0.01 \\
0.05(0.06 / 0.04)\end{array}$ & $\begin{array}{l}0.08 \pm 0.05 \\
0.07(0.08 / 0.04)\end{array}$ & $\begin{array}{l}0.31 \pm 0.13 \\
0.35(0.37 / 0.32)\end{array}$ & $16 \%$ \\
\hline WSOC $\left(\mathrm{ngC} \mathrm{m}^{-3}\right)$ & $\begin{array}{l}130 \pm 27 \\
113(159 / 109)\end{array}$ & $\begin{array}{l}85 \pm 24 \\
83(84 / 70)\end{array}$ & $\begin{array}{l}515 \pm 268 \\
588(603 / 572)\end{array}$ & $15 \%$ \\
\hline $\mathrm{TC}\left(\mathrm{ngC} \mathrm{m}^{-3}\right)$ & $\begin{array}{l}380 \pm 132 \\
337(377 / 324)\end{array}$ & $\begin{array}{l}322 \pm 160 \\
259(323 / 238)\end{array}$ & $\begin{array}{l}978 \pm 345 \\
973(1106 / 840)\end{array}$ & $9 \%$ \\
\hline WSOC / TC (\%) & $\begin{array}{l}36 \pm 10 \\
32(43 / 29)\end{array}$ & $\begin{array}{l}31 \pm 10 \\
30(30 / 24)\end{array}$ & $\begin{array}{l}62 \pm 19 \\
62(66 / 58)\end{array}$ & $17 \%$ \\
\hline$\delta^{13} \mathrm{CWSOC}_{\mathrm{W}}(\% \circ)$ & $\begin{array}{l}-19.1 \pm 0.7 \\
-19.3(-18.4 /-19.5)\end{array}$ & $\begin{array}{l}-19.6 \pm 2.2 \\
-18.4(-18.0 /-19.0)\end{array}$ & $\begin{array}{l}-18.8 \pm 1.2 \\
-18.7(-18.5 /-19.0)\end{array}$ & $0.7 \%$ \\
\hline$\delta^{13} \mathrm{C}_{\mathrm{TC}}(\% \circ)$ & $\begin{array}{l}-22.0 \pm 2.0 \\
-21.3(-21.0 /-23.9)\end{array}$ & $\begin{array}{l}-22.1 \pm 1.4 \\
-22.5(-22.0 /-22.7)\end{array}$ & $\begin{array}{l}-20.7 \pm 0.7 \\
-21.0(-20.9 /-21.2)\end{array}$ & $0.5 \%$ \\
\hline$\delta^{15} \mathrm{~N}_{\mathrm{WSTN}}(\% o)$ & $\begin{array}{l}10.1 \pm 1.3 \\
10.0(10.9 / 9.9)\end{array}$ & $\begin{array}{l}11.6 \pm 1.3 \\
11.4(11.5 / 11.3)\end{array}$ & $\begin{array}{l}12.8 \pm 5.4 \\
15.4(16.5 / 14.3)\end{array}$ & $0.8 \%$ \\
\hline Glucose $\left(\mathrm{ng} \mathrm{m}^{-3}\right)$ & $\begin{array}{l}0.11 \pm 0.04 \\
0.11(0.12 / 0.10)\end{array}$ & $\begin{array}{l}0.05 \pm 0.08 \\
0.03(0.03 / 0.02)\end{array}$ & $\begin{array}{l}1.55 \pm 0.66 \\
1.52(1.89 / 1.15)\end{array}$ & $13 \%$ \\
\hline Fructose $\left(\mathrm{ng} \mathrm{m}^{-3}\right)$ & $\begin{array}{l}0.02 \pm 0.01 \\
0.03(0.03 / 0.02)\end{array}$ & $\begin{array}{l}0.01 \pm 0.01 \\
0.01(0.01 / 0.00)\end{array}$ & $\begin{array}{l}0.48 \pm 0.30 \\
0.34(0.39 / 0.28)\end{array}$ & $13 \%$ \\
\hline Fatty acids $\left(\mathrm{C}_{12}-\mathrm{C}_{19}\right)\left(\mathrm{ng} \mathrm{m}^{-3}\right)$ & $\begin{array}{l}1.38 \pm 0.47 \\
0.97(1.40 / 0.69)\end{array}$ & $\begin{array}{l}3.60 \pm 2.20 \\
1.49(1.58 / 1.37)\end{array}$ & $\begin{array}{l}5.82 \pm 3.02 \\
3.32(3.77 / 2.86)\end{array}$ & $28 \%$ \\
\hline $\operatorname{MSA}\left(\mathrm{ng} \mathrm{m}^{-3}\right)$ & $\begin{array}{l}92 \pm 13 \\
99(102 / 82)\end{array}$ & $\begin{array}{l}141 \pm 21 \\
144(146 / 131)\end{array}$ & $\begin{array}{l}123 \pm 20 \\
118(121 / 114)\end{array}$ & $18 \%$ \\
\hline Chl $a\left(\mathrm{mg} \mathrm{m}^{-3}\right)$ & $\begin{array}{l}0.112 \pm 0.016 \\
0.107(0.129 / 0.100)\end{array}$ & $\begin{array}{l}0.106 \pm 0.015 \\
0.101(0.107 / 0.097)\end{array}$ & $\begin{array}{l}0.147 \pm 0.037 \\
0.125(0.127 / 0.123)\end{array}$ & NA \\
\hline
\end{tabular}

viously reported for submicron marine primary OA (Russell et al., 2010; Frossard et al., 2014). This result is consistent with our understanding that the submicron SSA is enriched in OC relative to seawater (O'Dowd et al., 2004: Keene et al., 2007). The enrichment of water-soluble organics in the submicron particles is particularly significant for R3 (Fig. 4b), where the average WSOC / $\mathrm{Na}^{+}$ratio $(0.31 \pm 0.13)$ was substantially higher than that in $\mathrm{R} 1$ $(0.05 \pm 0.01)$ and $\mathrm{R} 2(0.08 \pm 0.05)$ (Table 1). The enrichment of organics can be attributed to the phytoplankton blooms identified by the increased concentrations of Chl $a$ in seawater (up to $0.33 \mathrm{mg} \mathrm{m}^{-3}$ ) in R3 (Fig. 4e), together with the spatial distributions measured by the satellite (Fig. 1). Previ- ous studies have shown a linkage between organics and high Chl $a$ concentrations on timescales of months (O'Dowd et al., 2004; Sciare et al., 2009). However, Quinn et al. (2014) found no well-defined relationship between instantaneous $\mathrm{Chl} a$ in seawater and organic-mass enrichment in sea spray, suggesting no significant variability in the OC content of freshly emitted sea spray aerosol, despite significant variability in seawater Chl $a$ levels. This point will be discussed in Sect. 3.3. The higher WSOC $/ \mathrm{Na}^{+}$ratio in $\mathrm{R} 3$ can be also interpreted as an indicator of secondary contributions of photochemical products of primary $\mathrm{OA}$ and/or marine biogenic organic gas species to the observed aerosols during the ag- 


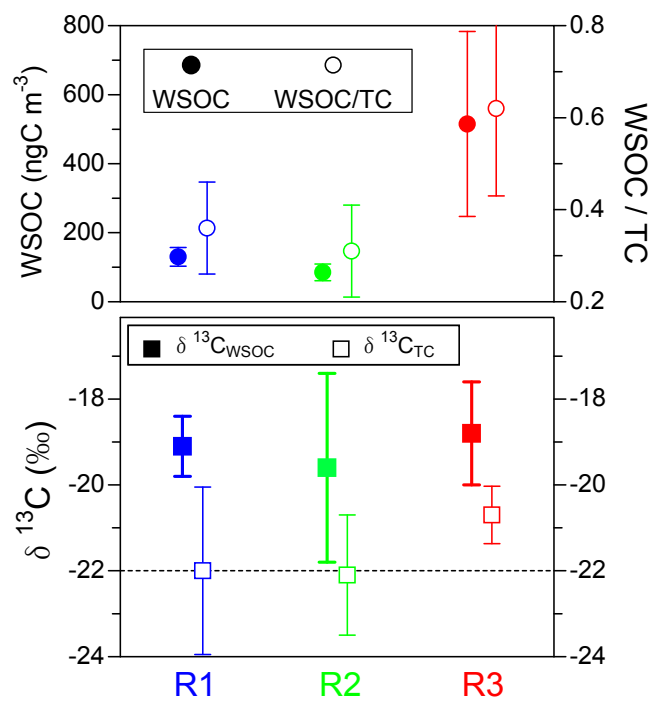

Figure 5. Average values of the WSOC concentration, the WSOC / TC ratio, $\delta^{13} \mathrm{C}_{\mathrm{TC}}$, and $\delta^{13} \mathrm{C}_{\mathrm{WSOC}}$ in each oceanic area.

ing, as indicated by the enhanced levels of $\mathrm{O}_{3}$ (up to $25 \mathrm{ppbv}$ ) (Fig. 4d) and the decreased $\mathrm{Cl}^{-} / \mathrm{Na}^{+}$ratio (Fig. 2).

\subsection{Isotopic characterization of aerosol WSOC and TC}

As shown in Fig. $4 \mathrm{c}$, the $\delta^{13} \mathrm{C}_{\mathrm{WSOC}}$ ranged from -23.0 to $-15.7 \%$, with an average of $-19.8 \pm 2.0 \%$ o during the cruise. The $\delta^{13} \mathrm{C}_{\mathrm{WSOC}}$ values were systematically higher than the $\delta^{13} \mathrm{C}_{\mathrm{TC}}$ ranging from -25.5 to $-19.7 \%$, with an average of $-21.8 \pm 1.4 \%$ (Fig. 5). On average, WSOC was enriched in ${ }^{13} \mathrm{C}$ by $\sim 2.0 \%$ relative to $\mathrm{TC}$, indicating that ${ }^{13} \mathrm{C}$-enriched submicron carbonaceous aerosol is preferentially water soluble. Regardless of the oceanic area, the average $\delta{ }^{13} \mathrm{C}_{\mathrm{WSOC}}$ values of -19.6 to $-18.8 \%$ o (Table 1 ) were within the typical range of $\delta^{13} \mathrm{C}$ in the DOC pool of seawater ( -22 to $-18 \%$; Fontugne and Duplessy, 1981). This range is influenced by factors such as local ocean temperatures and phytoplankton species, whereas changes in $\delta^{13} \mathrm{C}$ resulting from trophic transfers are minimal (e.g., Guo et al., 2003). In the eastern North Pacific and in tropical oceans, the $\delta^{13} \mathrm{C}$ of DOC typically ranges from -22 to $-20 \%$ in surface seawater (Bauer and Druffel, 1998). In contrast, relatively few studies have measured the $\delta^{13} \mathrm{C}$ signature in aerosol WSOC, which ranges from -25.5 to $-23 \%$ at rural and urban sites, and is generally attributable to terrestrial and fossil sources (Kirillova et al., 2010; Wozniak et al., 2012). The $\delta^{13} \mathrm{C}_{\text {WSOC }}$ measured in this study indicate an enrichment of sea-surfacederived DOC in submicron WSOC aerosols throughout the study region, and the ${ }^{13} \mathrm{C}$-enriched WSOC over TC cannot be explained by influences of land surface. It should be noted that this enrichment of ${ }^{13} \mathrm{C}$ in WSOC could be partly due to isotopic fractionation throughout the partitioning of semivolatile organics between the gas and particle phases (Fisseha et al., 2009). In equilibrium, partitioning between the gas and particle phases leads to larger ${ }^{13} \mathrm{C}$ of particle-phase organic compounds than the corresponding gas-phase compounds (Gensch et al., 2014). However, even if this effect $( \pm 2.0 \%)$ is taken into account, the $\delta^{13} \mathrm{C}_{\mathrm{WSOC}}$ values were still within the range of $\delta^{13} \mathrm{C}$ of DOC.

A combination of both carbon and nitrogen isotopic signatures can provide better information on the sources of dissolved organic matter (DOM) in marine aerosols than carbon isotopes alone. Figure 6 shows the ranges of the nitrogen isotope ratio of the water-soluble total nitrogen $\left(\delta^{15} \mathrm{~N}_{\mathrm{WSTN}}\right)$ and $\delta^{13} \mathrm{C}_{\mathrm{WSOC}}$ in the submicron aerosols for each oceanic region. The $\delta^{15} \mathrm{~N}_{\text {WSTN }}$ ranged between 3.5 and $16.7 \%$, with an average of $11.8 \pm 3.1 \%$. The wide range of $\delta^{15} \mathrm{~N}_{\mathrm{WSTN}}$ values was partly due to the fact that WSTN contains inorganic nitrogen, such as $\mathrm{NO}_{3}^{-}$and $\mathrm{NH}_{4}^{+}$, in addition to watersoluble organic nitrogen $(\mathrm{ON})$. In general, the observed values were similar to the $\delta^{15} \mathrm{~N}$ values in surface seawater (i.e., $2 \mathrm{~m}$ depth). Benner et al. (1997) reported a dataset of $\delta^{15} \mathrm{~N}$ values for marine high-molecular-weight DOM samples obtained in the Gulf of Mexico and the Pacific and Atlantic oceans, which ranged from 6.6 to $10.2 \%$. The $\delta^{15} \mathrm{~N}_{\mathrm{WSTN}}$ in aerosol also provide evidence of a significant contribution of DOC to the observed submicron aerosols.

Figure 7 shows the percentage exposure (percent of time over 7 days) of the sampled air mass to ocean and land surfaces along the cruise track as functions of altitude and time. The calculated air parcels were initialized at each sampling location along the cruise track. This Lagrangian trajectory analysis showed very low exposure $(<20 \%)$ of air parcels at the sampling points on the ship to boundary layers over land, consistent with the results of the isotopic analysis, and suggested that the majority of submicron WSOC originated from the sea surface during the study period. It is noted that the observed aerosols in R3 had been transported by lowlevel air flow from the Atlantic, as indicated by the back trajectories (Fig. 1). In fact, the trajectories had passed over the Isthmus of Panama at higher altitudes, followed by descent to the sampling point in R3 as seen in Fig. 1, indicating less influence from the land surface. This is consistent with the results from the isotopic analysis of WSOC, which suggest that the influence of the land surface on the observed WSOC was insignificant.

In R3, the elevated levels of WSOC along the cruise track were not always accompanied by the increase of Chl $a$ on a daily timescale. Specifically, the $\mathrm{Chl} a$ concentrations displayed an insignificant increase on 22 and 27-28 February, whereas the WSOC concentrations increased, ranging from 300 to $900 \mathrm{ngC} \mathrm{m}^{-3}$ during the same periods (Fig. 4a and e). Deng et al. (2014) also observed the lack of correlation between organics and Chl $a$ over the eastern Pacific. They attributed it to the small variation in Chl $a$ and the fact that aerosol composition is only sensitive to major changes in Chl $a$. Rinaldi et al. (2013) observed time lag between $\mathrm{Chl} a$ and $\mathrm{OM}$ enrichment in aerosol, suggesting that biological processes in oceanic surface waters and their timescales 


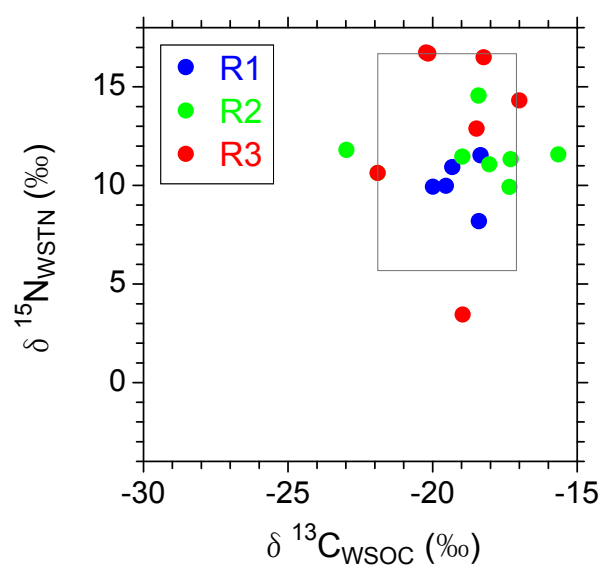

Figure 6. The ranges of the $\delta^{15} \mathrm{~N}_{\text {WSTN }}$ and $\delta^{13} \mathrm{C}_{\text {WSOC }}$ in the submicron aerosols obtained in each oceanic area. The rectangle in the panel indicates the typical ranges of $\delta^{15} \mathrm{~N}$ and $\delta^{13} \mathrm{C}$ for dissolved organic matter (DOM) in the eastern equatorial Pacific (see text).

should be considered when modeling the production of primary marine OA. Quinn et al. (2014) assessed the relationship between the OC content of seawater and freshly emitted SSA in the presence and absence of phytoplankton blooms in the North Atlantic and the coastal waters of California. They concluded that there is a large reservoir of OC in surface seawater that results in the enrichment of OC in SSA. They also reported that the oceanic source of OC in the region is uncoupled from, and overwhelms any influence of, local biological activity as measured by Chl $a$ over large ocean regions. O'Dowd et al. (2015) showed that a correlation between OM in sea salt particles and Chl $a$ increased as the timescale increased from daily to monthly intervals and suggested that OM production is closely linked with the decay phase of the bloom and is driven by nanoscale biological processes that release large quantities of transferable OM in surface seawater. The results of our study support those of previous studies in showing that linear source functions based on Chl $a$ might not properly predict OC enrichments for SSA on the timescale considered here.

\subsection{Monosaccharides, fatty acids, and MSA as marine biogenic tracers}

We also used several organic molecular markers to further investigate the contribution of DOC to the submicron organics in concert with the isotope tracers described previously. The analysis of sea surface waters for organics has revealed a significant carbohydrate concentration, including glucose (Aluwihare et al., 1997), whereas primary saccharides (e.g., glucose) in aerosol have been suggested as possible tracers for surface soil dust and/or biomass burning (Simoneit et al., 2004). Electron ionization-mass spectrometry (EI-MS) measurements of marine aerosol in the western Pacific revealed substantial contributions from carbohydrates such as glucose and levoglucosan, and the former is partially attributed to organics from the ocean surface (Crahan et al., 2004). Lowmolecular-weight LMW FAs have multiple sources associated with marine microbial activity, vascular plants, and microbes (Mochida et al., 2002; Kawamura et al., 2003). Burrows et al. (2014) introduced a framework for parameterizing the fractionation of marine OM into SSA and partitioned marine $\mathrm{OM}$ into different classes, including a polysaccharidelike mixture associated with semilabile DOC, a lipid-like mixture associated with labile DOC, and others. In this study, we investigated the possible contributions of types of DOC to submicron organics using the molecular markers of DOC.

Figure $8 \mathrm{a}-\mathrm{b}$ show a time series of concentrations of glucose, fructose, and LMW FAs $\left(\mathrm{C}_{12}-\mathrm{C}_{19}\right)$ in the submicron particles collected. The concentrations of both glucose and fructose were elevated in R3, with average values of $1.6 \pm 0.7$ and $0.5 \pm 0.3 \mathrm{ng} \mathrm{m}^{-3}$, respectively. The observed concentrations of glucose and LMW FAs were similar to those observed in total suspended particulate matter (TSP) over coastal areas in California and western Mexico (1.0-1.4 and $1.0-6.0 \mathrm{ng} \mathrm{m}^{-3}$ for glucose and LMW FAs, respectively) (Fu et al., 2011). The temporal trends of these saccharides were similar to that of WSOC, with $r^{2}$ of $0.82(n=21)$. The mass ratio of (glucose + fructose) $/ \mathrm{Na}^{+}$was substantially higher in R3 compared to the other regions, indicating an enrichment of these monosaccharides in submicron sea salt particles over oceanic areas with high biological activity. In contrast, the correlation between LMW FAs and WSOC was less significant $\left(r^{2}=0.31\right)$. The combined results of the organic molecular tracers and $\delta^{13} \mathrm{C}_{\mathrm{WSOC}}$ indicate a substantial contribution of saccharide-related DOC associated with sea spray to submicron WSOC. The results also suggest that the monosaccharides detected here might be suitable indicators for the ocean-derived submicron WSOC over the study region.

Russell et al. (2010) used reference Fourier transform infrared (FTIR) spectra of 11 different saccharides, including glucose, and found that a majority of organic component in ambient marine submicron aerosol consisted of organic hydroxyl groups characteristic of saccharides. Frossard et al. (2014) observed a significant amount of monosaccharides and disaccharides in model-generated primary marine aerosols from bubbled seawater, whereas the organic mass hydroxyl group in seawater was mostly characterized by polysaccharides. They attributed this finding to the larger saccharides preferentially remaining in the seawater during the primary OA production. Miyazaki et al. (2014) found lactic and glycolic acids, which are LMW hydroxyacids that can be produced as the major metabolic end products of carbohydrate fermentation, in marine aerosols obtained from biologically active oceanic regions of the western North Pacific. The results of our study on glucose and fructose in the submicron WSOC were consistent with the chemical signatures of marine OA reported in those studies. Moreover, our result is in line with a modeling study by Burrows et al. (2014), who 


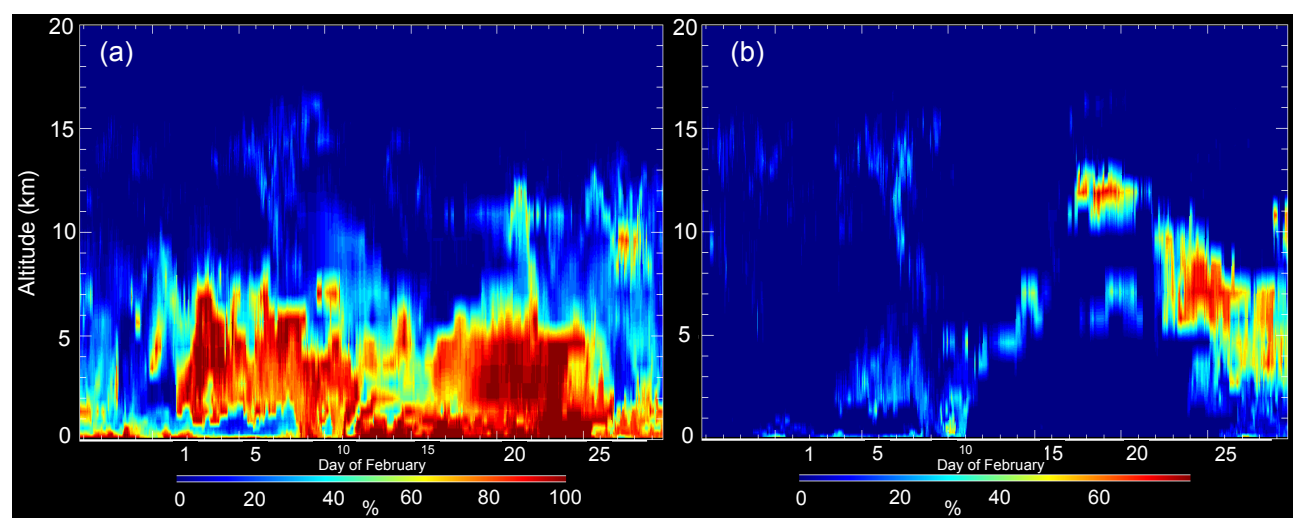

Figure 7. The percentage exposure of the 7-day air mass to the (a) maritime and (b) continental planetary boundary layer as functions of altitude and time. The calculation was made along the TORERO cruise track with the Real-time Air Quality Modeling System (RAQMS).

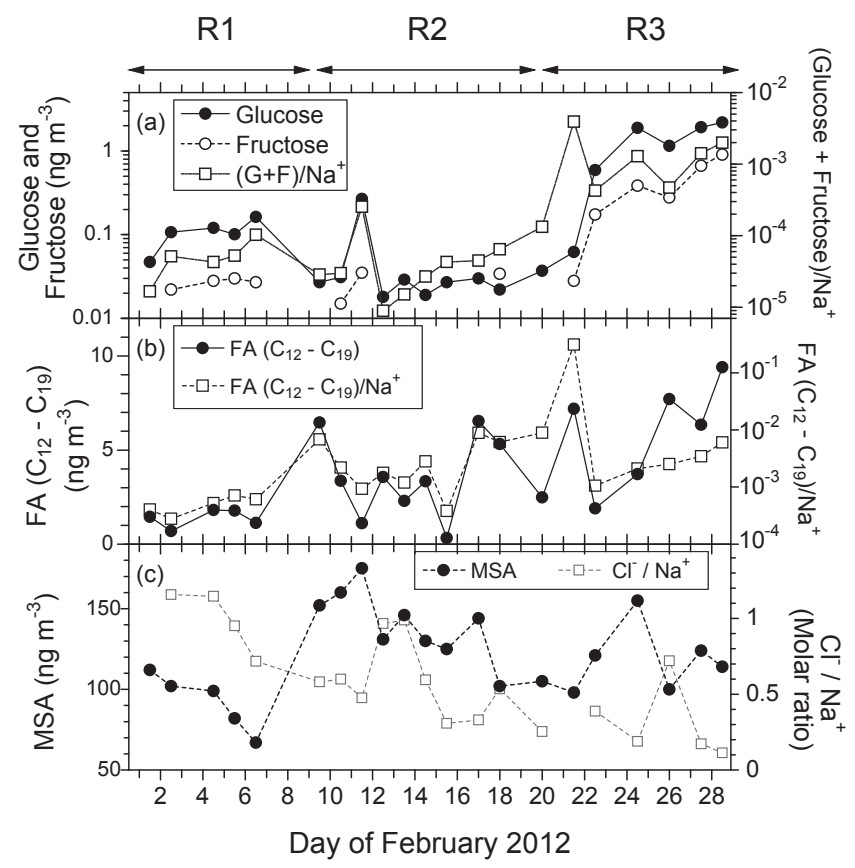

Figure 8. Time series of the concentrations of (a) glucose and fructose with their ratios to $\mathrm{Na}^{+}$, (b) fatty acids $\left(\mathrm{C}_{12}-\mathrm{C}_{19}\right)$ with their ratios to $\mathrm{Na}^{+}$, and (c) methanesulfonic acid (MSA) and the $\mathrm{Cl}^{-} / \mathrm{Na}^{+}$molar ratios in the submicron aerosol samples collected during the cruise.

simulated that, in regions such as the Southeast Pacific, semilabile DOM contributes significantly to estimated aerosol organic mass as saccharides and proteins. They also reported an anticorrelation between $\mathrm{Chl} a$ and $\mathrm{OM}$ fraction in their model. Contributions of proteins to the submicron WSOC in the same samples are discussed in Chen et al. (2016) using excitation-emission matrices.

MSA in aerosol is also considered a marker of marine biogenic origin, because it is a major oxidation product of dimethyl sulphide (DMS). The mass concentration of MSA increased in R2, with an average of $141 \mathrm{ng} \mathrm{m}^{-3}$, which was greater than in R3 (123 $\mathrm{ng} \mathrm{m}^{-3}$ ) (Fig. 8c). The increase in the background level of MSA did not necessarily accompany the increase in the background level of WSOC in R2 (Fig. 4a). In fact, a globally coupled ocean-atmosphere model calculation showed a "hot spot" of mean sea surface DMS in the upwelling zones of the eastern equatorial Pacific from December to May whose oceanic area corresponded to R2 (Kloster et al., 2006).

The observed MSA is considered to be either produced by gas-phase MSA directly scavenged by aerosols or rapidly produced in aqueous phase from scavenged dimethylsulfoxide (DMSO) and methanesulfinic acid (MSIA) (Zhu et al., 2006), particularly under conditions with high relative humidity typical of the MBL. Assuming a typical average $\mathrm{OH}$ concentration of $1 \times 10^{6} \mathrm{~cm}^{-3}$, a lifetime of DMS is roughly estimated to be $<\sim 1$ day with respect to oxidation by $\mathrm{OH}$ in the MBL (Davis et al., 1999; Kloster et al., 2006). The rapid oxidation of the intermediate reaction products of DMS to produce MSA (on a timescale of hours) and the typical residence time of submicron aerosols in the MBL ( 5-7 days) indicate that the measured MSA likely reflects the larger emission of DMS around the sampling locations of R2. Additionally, a large missing source of MSA photolytically enhanced during the daytime has been as suggested by Zhang et al. (2014) and would be consistent with the lowest solar zenith angle in R2 (Coburn et al., 2014). The MSA concentrations generally increased with the decreasing $\mathrm{Cl}^{-} / \mathrm{Na}^{+}$ ratios (Fig. 8c), which is consistent with the chemical aging of the observed aerosols. Another possible reaction of DMS with species other than $\mathrm{OH}$ to produce MSA includes BrO+DMS (Saiz-Lopez et al., 2004). However, BrO in the MBL over this region was extremely low (generally below 0.5 pptv) during the same observational period (Volkamer et al., 2015), indicating that the reaction of $\mathrm{BrO}+\mathrm{DMS}$ is likely insignificant source for MSA. Gaston et al. (2010) suggested a possible catalytic role of vanadium in MSA formation. The observed increases in the MSA concentrations were most ev- 
ident in R2, in which the impacts of anthropogenic sources appeared to be very low. Therefore, the effects of such a catalytic reaction on the increases in MSA concentrations in R2 are likely insignificant. The lack of correlation between MSA and WSOC implies that the presence of DMS in seawater and its subsequent oxidation to MSA were not necessarily linked to the formation of submicron WSOC over this oceanic region. This confirms the difficulties of connecting Chl $a$ with DMS concentrations in seawater over subtropical and tropical ocean as previously suggested (Bell et al., 2010).

\subsection{Contribution of marine OC sources to the WSOC aerosol}

To estimate the relative contribution from marine and terrestrial OC sources to the observed WSOC, an isotopic mass balance equation assuming a two-end-member isotopic mixing was used (e.g., Turekian et al., 2003; Miyazaki et al., 2010). We applied ${ }^{13} \mathrm{C}$ values ranging from -22 to $-18 \%$ o for marine OC and those ranging from -27 to $-26 \%$ for terrestrial OC (e.g., Kirillova et al., 2010) typically found in the Northern Hemisphere. The effect of isotopic fractionation by heterotrophic degradation on $\mathrm{OM}$ is considerably small ( $\sim 1 \%$ o for ${ }^{13} \mathrm{C}$; Shaffer et al., 1999). Our calculation indicates that, on average, marine sources contribute $\sim 90 \pm 25 \%$ of the aerosol carbon. As discussed previously, the higher WSOC $/ \mathrm{Na}^{+}$ratio in $\mathrm{R} 3$ indicates some contribution of a secondary, ocean-derived source to WSOC, although it is difficult to quantify their contributions to the WSOC mass.

The results of our study contradict those of Shank et al. (2012), who suggested that there was little to no marine source of submicron $\mathrm{OA}$ to the atmosphere in a similar oceanic region (corresponding to $\mathrm{R} 1$ and $\mathrm{R} 2$ in the current study) over the eastern South Pacific. Shank et al. (2012) reported the average concentrations of non-refractory organics in submicron aerosols to be as low as $70 \mathrm{ng} \mathrm{m}^{-3}$ with a maximum of $170 \mathrm{ng} \mathrm{m}^{-3}$ at most measured with an Aerodyne high-resolution time-of-flight mass spectrometer (HR-ToFAMS). Assuming that most of the TC in this study can be attributed to OC in R1 and R2 and given OC-to-OM conversion factors of 1.8 for water-soluble $\mathrm{OM}$ and 1.4 for waterinsoluble OM reported for the marine OA (Facchini et al., 2008), the average OA concentration in R1 and R2 is estimated to be $\sim 490-580 \mathrm{ng} \mathrm{m}^{-3}$ (cf. Table 1). These values are substantially larger than those reported by Shank et al. (2012). One possible explanation for the contradiction between our study and Shank et al. (2012) is that the studies were conducted in different seasons with different meteorological conditions and microbial activity at the sea surface. Another possible explanation is that the AMS could not detect a significant fraction of refractory material (e.g., HULIS) found in primary marine OA over the study region (Deng et al., 2014). Our analysis of $\delta^{13} \mathrm{C}_{\mathrm{WSOC}}$ and organic molecular markers indicated that DOC in surface seawater contributed substantially to the submicron WSOC levels regardless of the oceanic area of the study region. It is noted that the contribution of anthropogenic sources cannot be negligible although this is indicated by the isotopic analysis. Nevertheless, the present study demonstrates that DOC is closely correlated with the submicron WSOC aerosol concentration and implies that it may characterize background OA in the MBL over the study region.

\section{Conclusions}

Isotopic and organic molecular characterization of submicron WSOC aerosols provided an evidence of a significant contribution of marine DOC to submicron particles in the MBL during the TORERO/KA-12-01 cruise. On average, the WSOC fraction of the TC mass in submicron aerosols was $\sim 30-35 \%$ in the low-Chl $a$ regions, whereas it was $\sim 60 \%$ in the high-Chl $a$ regions over the eastern equatorial Pacific. The average $\delta^{13} \mathrm{C}_{\mathrm{WSOC}}(-19.8 \pm 2.0 \%$ ) was systematically higher than $\delta^{13} \mathrm{C}_{\mathrm{TC}}(-22.2 \pm 1.9 \%$ ) during the entire cruise. This was attributed to greater enrichment of planktonic tissues in $\delta^{13} \mathrm{C}$ in the submicron WSOC. We found that the $\delta^{13} \mathrm{C}_{\text {WSOC }}$ was close to the typical values of $\delta^{13} \mathrm{C}$ for DOC in surface seawater throughout the cruise, suggesting enrichment of marine DOC in WSOC aerosols regardless of the oceanic area of the study region.

Enhanced levels of WSOC and monosaccharides (i.e., glucose and fructose) together with an elevated WSOC / TC ( $\sim 60 \%$ ) were observed over the upwelling areas and coastal regions. The $\delta^{13} \mathrm{C}$ analysis indicated that marine-derived carbon accounted for $\sim 90 \%$ of submicron WSOC. This finding was supported by a Lagrangian trajectory analysis, which suggested little exposure of air parcels at the sampling points to planetary boundary layer air over 7 days prior to the sampling. The lack of correlation between MSA and WSOC implies that the presence of DMS in seawater was not necessarily linked to the formation of submicron WSOC, consistent with the difficulties in connecting Chl $a$ with DMS concentrations in seawater over this oceanic region. The combined results of the organic molecular tracers and $\delta^{13} \mathrm{C}_{\mathrm{WSOC}}$ suggest that the monosaccharide might be a suitable indicator for the ocean-derived submicron WSOC associated with sea salt over this oceanic region. This study provided direct evidence that the contribution of DOC was significantly correlated with the submicron WSOC mass across the study region regardless of the oceanic area.

\section{Data availability}

The data used in this study is available on request to $\mathrm{Y}$. Miyazaki. The TORERO data is also available at http://data. eol.ucar.edu/master_list/?project=TORERO. 
Acknowledgements. We thank all the researchers and crew of the NOAA R/V Ka'imimoana for their help with the observations, and the NOAA TAO program for cruise KA-12-01. This study was in part supported by Grant in-Aid for Scientific Research (B) (25281002) from the Ministry of Education, Culture, Sports, Science and Technology (MEXT), Japan. The TORERO project was funded by US National Science Foundation award AGS-1104104 (PI: R. Volkamer). Sean Coburn is the recipient of a NASA graduate fellowship. The views, opinions and findings contained in this paper are those of the authors and should not be construed as an official National Oceanic and Atmospheric Administration or US Government position, policy or decision.

Edited by: A. Pszenny

\section{References}

Aluwihare, L. I., Repeta, D. J., and Chen, R. F.: A major biopolymeric component to dissolved organic carbon in surface sea water, Nature, 387, 166-169, 1997.

Bauer, J. and Druffel, E.: Ocean margins as a significant source of organic matter to the deep open ocean, Nature, 392, 482-485, 1998.

Bell, T. G., Poulton, A. J., and Malin, G.: Strong linkages between dimethylsulphoniopropionate (DMSP) and phytoplankton community physiology in a large subtropical and tropical Atlantic Ocean data set, Global Biogeochem. Cy., 24, GB3009, doi:10.1029/2009GB003617, 2010.

Benner, R., Biddanda, B., Black, B., and McCarthy, M.: Abundance, size distribution, and stable carbon and nitrogen isotopic compositions of marine organic matter isolated by tangential-flow ultrafiltration, Mar. Chem., 57, 243-263, 1997.

Burrows, S. M., Ogunro, O., Frossard, A. A., Russell, L. M., Rasch, P. J., and Elliott, S. M.: A physically based framework for modeling the organic fractionation of sea spray aerosol from bubble film Langmuir equilibria, Atmos. Chem. Phys., 14, 1360113629, doi:10.5194/acp-14-13601-2014, 2014.

Cachier, H., Buat-Ménard, M. P., Fontugne, M., and Chesselet, R.: Long-range transport of continentally-derived particulate carbon in the marine atmosphere: Evidence from stable carbon isotope studies, Tellus, Ser. B, 38, 161-177, 1986.

Ceburnis, D., Garbaras, A., Szidat, S., Rinaldi, M., Fahrni, S., Perron, N., Wacker, L., Leinert, S., Remeikis, V., Facchini, M. C., Prevot, A. S. H., Jennings, S. G., Ramonet, M., and O'Dowd, C. D.: Quantification of the carbonaceous matter origin in submicron marine aerosol by ${ }^{13} \mathrm{C}$ and ${ }^{14} \mathrm{C}$ isotope analysis, Atmos. Chem. Phys., 11, 8593-8606, doi:10.5194/acp-11-85932011, 2011.

Chen, Q., Miyazaki, Y., Kawamura, K., Matsumoto, K., Cobern, S., Volkamer, R., Iwamoto, Y., Kagami, S., Deng, Y., Ogawa, S., Sathiyamurthi, R., Kato, S., Ida, A., Kajii, Y., and Mochida, M.: Characterization of chromophoric water-soluble organics in urban, forest and marine aerosols by HR-ToF-AMS analysis and excitation-emission matrix spectroscopy, Environ. Sci. Technol., in revision, 2016.

Chesselet, R., Fontugne, M., Buatmenard, P., Ezat, U., and Lambert, C. E.: The origin of particulate organic carbon in the marine at- mosphere as indicated by its stable carbon isotopic composition, Geophys. Res. Lett., 8, 345-348, 1981.

Coburn, S., Ortega, I., Thalman, R., Blomquist, B., Fairall, C. W., and Volkamer, R.: Measurements of diurnal variations and eddy covariance (EC) fluxes of glyoxal in the tropical marine boundary layer: description of the Fast LED-CE-DOAS instrument, Atmos. Meas. Tech., 7, 3579-3595, doi:10.5194/amt-7-3579-2014, 2014.

Crahan, K. K., Hegg, D. A., Covert, D. S., Jonsson, H., Reid, J. S., Khelif D., and Brooks, B. J.: Speciation of organic aerosols in the tropical mid-Pacific and their relationship to light scattering, J. Atmos. Sci., 61, 21, 2544-2558, 2004.

Davis, D., Chen, G., Bandy, A., Thornton, D., Eisele, F., Mauldin, L., Tanner, D., Lenschow, D., Fuelberg, H., Huebert, B., Heath, J., Clarke, A., and Blake, D.: Dimethyl sulfide oxidation in the equatorial Pacific: Comparison of model simulations with field observations for DMS, $\mathrm{SO}_{2}, \mathrm{H}_{2} \mathrm{SO}_{4}(\mathrm{~g}), \mathrm{MSA}(\mathrm{g})$, and MS, and NSS, J. Geophys. Res., 104, 5765-5784, 1999.

Deng, C., Brooks, S. D., Vidaurre, G., and Thornton, D. C. O.: Using Raman microspectroscopy to determine chemical composition and mixing state of airborne marine aerosols over the Pacific ocean, Aerosol Sci. Tech., 48, 193-206, 2014.

Facchini, M. C., Rinaldi, M., Decesari, S., Carbone, C., Finessi, E., Mircea, M., Fuzzi, S., Ceburnis, D., Flanagan, R., Nilsson, E. D., de Leeuw, G., Martino, M., Woeltjen, J., and O'Dowd, C. D.: Primary submicron marine aerosol dominated by insoluble organic colloids and aggregates, Geophys. Res. Lett., 35, L17814, doi:10.1029/2008GL034210, 2008.

Fisseha, R., Saurer, M., Jaggi, M., Siegwolf, R. T. W., Dommen, J., Szidat, S., Sam-burova, V., and Baltensperger, U.: Determination of primary and secondary sources oforganic acids and carbonaceous aerosols using stable carbon isotopes, Atmos. Environ., 43, 431-437, 2009.

Fontugne, M. R. and Duplessy, J. C.: Organic carbon isotopic fractionation be marine plankton in the temperature range -1 to $30^{\circ} \mathrm{C}$, Oceanol. Acta, 4, 85-90, 1981.

Frossard, A. A., Russell, L. M., Burrows, S. M., Elliott, S. M., Bates, T. S., and Quinn, P. K.: Sources and composition of submicron organic mass in marine aerosol particles, J. Geophys. Res. Atmos., 119, 12977-13003, doi:10.1002/2014JD021913, 2014.

Fry, B. and Sherr, E. B.: $\delta^{13} \mathrm{C}$ measurements as indicators of carbon flow in marine and freshwater ecosystems, Stable Isotopes in Ecological Research, Volume 68 of the series Ecological Studies, 196-229, 1984.

Fu, P., Kawamura, K., and Miura, K.: Molecular characterization of marine organic aerosols collected during a round-the-world cruise, J. Geophys. Res., 116, D13302, doi:10.1029/2011JD015604, 2011.

Gaston, C. J., Pratt, K. A., Qin, X. Y., and Prather, K. A.: Real-time detection and mixing state of methanesulfonate in single particles at an inland urban location during a phytoplankton bloom, Environ. Sci. Technol., 44, 1566-1572, 2010.

Gensch, I., Kiendler-Scharr, A., and Rudolph J.: Isotope ratio studies of atmospheric organic compounds: Principles, methods, applications and potential, Int. J. Mass Spectrom., 365-366, 206221, doi:10.1016/j.ijms.2014.02.004, 2014.

Guo, L., Tanaka, N., Schell, D. M., and Santschi, P. H.: Nitrogen and carbon isotopic composition of high-molecular-weight dissolved 
organic matter in marine environments, Mar. Ecol. Prog. Ser., 252, 51-60, 2003.

Halpern, B. S., Walbridge, S., Selkoe, K. A., Kappel, C. V., Micheli, F., D’Agrosa, C., Bruno, J. F., Casey, K. S., Ebert, C., Fox, H. E., Fujita, R., Heinemann, D., Lenihan, H. S., Madin, E. M. P., Perry, M. T., Selig, E. R., Spalding, M., Steneck, R., and Watson, R.: A Global Map of Human Impact on marine ecosystems, Science, 948, 948-952, 2008.

Kawamura, K., Ishimura, Y., and Yamazaki, K.: Four years' observations of terrestrial lipid class compounds in marine aerosols from the western North Pacific, Global Biogeochem. Cy., 17, 1003, doi:10.1029/2001GB001810, 2003.

Kawamura, K., Kobayashi, M., Tsubonuma, N., Mochida, M., Watanabe, T., and Lee, M.: Organic and inorganic compositions of marine aerosols from East Asia: Seasonal variations of water soluble dicarboxylic acids, major ions, total carbon and nitrogen, and stable $\mathrm{C}$ and $\mathrm{N}$ isotopic composition, in: Geochemical Investigation in Earth and Space Science; A Tribute to Issac R. Kaplan, The Geochemical Society, 9, Elsevier, 243-265, 2004.

Keene,W. C., Maring, H., Maben, J. R., Kieber, D.J.,Pszenny, A. A. P., Dahl, E. E., Izaguirre, M. A., Davis, A. J., Long, M. S., Zhou, X., Smoydzin, L., and Sander, R.: Chemical and physical characteristics of nascent aerosols produced by bursting bubbles at a model air-sea interface, J. Geophys. Res., 112, D21202, doi:10.1029/2007JD008464, 2007.

Keene, W. C., Long, M. S., Pszenny, A. A. P., Sander, R., Maben, J. R., Wall, A. J., O’Halloran, T. L., Kerkweg, A., Fischer, E. V., and Schrems, O.: Latitudinal variation in the multiphase chemical processing of inorganic halogens and related species over the eastern North and South Atlantic Oceans, Atmos. Chem. Phys., 9, 7361-7385, doi:10.5194/acp-9-7361-2009, 2009.

Kirillova, E. N., Sheesley, R. J., Andersson, A., and Gustafsson, $\varnothing$ : Natural abundance ${ }^{13} \mathrm{C}$ and ${ }^{14} \mathrm{C}$ analysis of water-soluble organic carbon in atmospheric aerosols, Anal. Chem., 82, 79737978, 2010.

Kloster, S., Feichter, J., Maier-Reimer, E., Six, K. D., Stier, P., and Wetzel, P.: DMS cycle in the marine ocean-atmosphere system a global model study, Biogeosciences, 3, 29-51, doi:10.5194/bg3-29-2006, 2006.

Laskin, A., Moffet, R. C., Gilles, M. K., Fast, J. D., Zaveri, R. A., Wang, B., Nigge, P., and Shutthanandan, J.: Tropospheric chemistry of internally mixed sea salt and organic particles: Surprising reactivity of $\mathrm{NaCl}$ with weak organic acids, J. Geophys. Res., 117, D15302, doi:10.1029/2012JD017743, 2012.

Long, M. S., Keene, W. C., Kieber, D. J., Erickson, D. J., and Maring, H.: A sea-state based source function for size- and composition-resolved marine aerosol production, Atmos. Chem. Phys., 11, 1203-1216, doi:10.5194/acp-11-1203-2011, 2011.

Maudlin, L. C., Wang, Z., Jonsson, H. H., and Sorooshian, A.: Impact of wildfires on size-resolved aerosol composition at a coastal California site, Atmos. Environ., 119, 59-68, doi:10.1016/j.atmosenv.2015.08.039, 2015.

Miyazaki, Y., Kawamura, K., and Sawano, M.: Size distributions of organic nitrogen and carbon in remote marine aerosols: Evidence of marine biological origin based on their isotopic ratios, Geophys. Res. Lett., 37, L06803, doi:10.1029/2010GL042483, 2010.

Miyazaki, Y., Kawamura, K., Jung, J., Furutani, H., and Uematsu, M.: Latitudinal distributions of organic nitrogen and organic car- bon in marine aerosols over the western North Pacific, Atmos. Chem. Phys., 11, 3037-3049, doi:10.5194/acp-11-3037-2011, 2011.

Miyazaki, Y., Fu, P. Q., Kawamura, K., Mizoguchi, Y., and Yamanoi, K.: Seasonal variations of stable carbon isotopic composition and biogenic tracer compounds of water-soluble organic aerosols in a deciduous forest, Atmos. Chem. Phys., 12, 13671376, doi:10.5194/acp-12-1367-2012, 2012.

Miyazaki, Y., Sawano, M., and Kawamura, K.: Low-molecularweight hydroxyacids in marine atmospheric aerosol: evidence of a marine microbial origin, Biogeosciences, 11, 4407-4414, doi:10.5194/bg-11-4407-2014, 2014.

Mochida, M., Kitamori, Y., Kawamura, K., Nojiri, Y., and Suzuki, K.: Fatty acids in the marine atmosphere: Factors governing their concentrations and evaluation of organic films on sea-salt particles, J. Geophys. Res., 107, 4325, doi:10.1029/2001JD001278, 2002.

O'Dowd, C. and de Leeuw, G.: Marine aerosol production: a review of the current knowledge, Philosophical Transactions of the Royal Society A: Mathematical, Physical and Engineering Sciences, 365, 1753-1774, 2007.

O’Dowd, C., Facchini, M. C., Cavalli, F., Ceburnis, D., Mircea, M., Decesari, S., Fuzzi, S., Yoon, Y. J., and Putaud, J.-P.: Biogenically driven organic contribution to marine aerosol, Nature, 431, 676-680, 2004.

O’Dowd, C., Ceburnis, D., Ovadnevaite, J., Bialek, J., Stengel, D. B., Zacharias, M., Nitschke, U., Connan, S., Rinaldi, M., Fuzzi, S., Decesari, S., Facchini, M. C., Marullo, S., Santoleri, R., Dell'Anno, A., Corinaldesi, C., Tangherlini, M., and Danovaro, R.: Connecting marine productivity to sea-spray via nanoscale biological processes: Phytoplankton Dance or Death Disco?, Sci. Rep., 5, 14883, doi:10.1038/srep14883, 2015.

Ovadnevaite, J., Ceburnis, D., Canagaratna, M., Berresheim, H., Bialek, J., Martucci, G., Worsnop, D. R., and O’Dowd, C.: On the effect of wind speed on submicron sea salt mass concentrations and source fluxes, J. Geophys. Res. Atmos., 117, D16201, doi:10.1029/2011jd017379, 2012.

Pennington, J. T., Mahoney, K. L., Kuwahara, V. S., Kolber, D. D., Calienes, R., and Chavez, F. P.: Primary production in the eastern tropical Pacific: A review, Progr. Oceanogr., 69, 285-317, 2006.

Pierce, R. B. and Fairlie, T. D. A.: Chaotic advection in the stratosphere: implications for the dispersal of chemically perturbed air from the polar vortex, J. Geophys. Res.-Atmos., 98, 1858918595, 1993.

Pierce, R. B., Schaack, T., Al-Saadi, J. A., Fairlie, T. D., Kittaka, C., Lingenfelser, G., Natarajan, M., Olson, J., Soja, A., Zapotocny, T., Lenzen, A., Stobie, J., Johnson, D., Avery, M. A., Sachse1, G. W., Thompson, A., Cohen, R., Dibb, J. E., Crawford, J., Rault, D., Martin, R., Szykman, J., and Fishman, J.: Chemical data assimilation estimates of continental U.S. ozone and nitrogen budgets during the Intercontinental Chemical Transport Experiment-North America, J. Geophys. Res., 112, D12S21, doi:10.1029/2006JD007722, 2007.

Prather, K. A., Bertram, T. H., Grassian, V. H., Deane, G. B., Stokes, M. D., DeMott, P. J., Aluwihare, L. I., Palenik, B. P., Azam, F., Seinfeld, J. H., Moffet, R. C., Molina, M. J., Cappa, C. D., Geiger, F. M., Roberts, G. C., Russell, L. M., Ault, A. P., Baltrusaitis, J., Collins, D. B., Corrigan, C. E., Cuadra-Rodriguez, L. A., Ebben, C. J., Forestieri, S. D., Guasco, T. L., Hersey, S. 
P., Kim, M. J., Lambert, W. F., Modini, R. L., Mui, W., Pedler, B. E., Ruppel, M. J., Ryder, O. S., Schoepp, N. G., Sullivan, R. C., and Zhao, D.: Bringing the ocean into the laboratory to probe the chemical complexity of sea spray aerosol, P. Natl. Acad. Sci. USA, 110, 7550-7555, doi:10.1073/pnas.1300262110, 2013.

Pszenny, A. A. P., Moldanová, J., Keene, W. C., Sander, R., Maben, J. R., Martinez, M., Crutzen, P. J., Perner, D., and Prinn, R. G.: Halogen cycling and aerosol $\mathrm{pH}$ in the Hawaiian marine boundary layer, Atmos. Chem. Phys., 4, 147-168, doi:10.5194/acp-4147-2004, 2004.

Quinn, P. K., Bates, T. S., Schulz, K. S., Coffman, D. J., Frossard, A. A., Russell, L. M., Keene, W. C., and Kieber, D. J.: Contribution of sea surface carbon pool to organic matter enrichment in sea spray aerosol, Nat. Geosci., 7, 228-232, 2014.

Rinaldi, M., Fuzzi, S., Decesari, S., Marullo, S., Santoleri, R., Provenzale, A., Hardenberg, J., Ceburnis, D., Vaishya, A., O'Dowd, C. D., and Facchini, M. C.: Is chlorophyll-a the best surrogate for organic matter enrichment in submicron primary marine aerosol?, J. Geophys. Res.-Atmos., 118, 4964-4973, doi:10.1002/jgrd.50417, 2013.

Rossi, V., López, C., Hernández-García, E., Sudre, J., Garcºn, V., and Morel, Y.: Surface mixing and biological activity in the four Eastern Boundary Upwelling Systems, Nonlin. Processes Geophys., 16, 557-568, doi:10.5194/npg-16-557-2009, 2009.

Russell, L. M., Hawkins, L. N., Frossard, A. A., Quinn, P. K., and Bates, T. S.: Carbohydrate-like composition of submicron atmospheric particles and their production from ocean bubble bursting, Proc. Natl. Acad. Sci. USA, 107, 6652-6657, 2010.

Saiz-Lopez, A., Plane, J. M. C., and Shillito, J. A.: Bromine oxide in the mid-latitude marine boundary layer, Geophys. Res. Lett, 31, L03111, doi:10.1029/2003GL018956, 2004.

Sciare, J., Favez, O., Sarda-Estève, R., Oikonomou, K., Cachier, H., and Kazan, V.: Long-term observations of carbonaceous aerosols in the Austral Ocean atmosphere: Evidence of a biogenic marine organic source, J. Geophys. Res., 114, D15302, doi:10.1029/2009JD011998, 2009.

Shaffer, G., Bendtsen, J., and Ulloa, O.: Fractionation during remineralization of organic matter in the ocean, Deep-Sea Res., 46, 185-204, 1999.

Shank, L. M., Howell, S., Clarke, A. D., Freitag, S., Brekhovskikh, V., Kapustin, V., McNaughton, C., Campos, T., and Wood, R.: Organic matter and non-refractory aerosol over the remote Southeast Pacific: oceanic and combustion sources, Atmos. Chem. Phys., 12, 557-576, doi:10.5194/acp-12-557-2012, 2012.
Simoneit, B. R. T., Kobayashi, M., Mochida, M., Kawamura, K., Lee, M., Lim, H.-J., Turpin, B. J., and Komazaki, Y.: Composition and major sources of organic compounds of aerosol particulate matter sampled during the ACE-Asia campaign, J. Geophys. Res., 109, D19S10, doi:10.1029/2004JD004598, 2004.

Spracklen, D. V., Arnold, S. R., Carslaw, K. S., Sciare, J., and Pio, C.: Globally significant oceanic source of organic carbon aerosol, Geophys. Res. Lett., 35, L12811, doi:10.1029/2008GL033359, 2008.

Sutton, R. T., Maclean, H., Swinbank, R., O’Neill, A., and Taylor, F. W.: High resolution stratospheric tracer fields estimated from satellite observations using Lagrangian trajectory calculations, J. Atmos. Sci., 51, 2995-3005, doi:10.1175/15200469(1994)051<2995:HRSTFE>2.0.CO;2, 1994.

Turekian, V. C., Macko, S. A., and Keene, W. C.: Concentrations, isotopic compositions, and sources of size-resolved, particulate organic carbon and oxalate in near-surface marine air at Bermuda during spring, J. Geophys. Res., 108, 4157, doi:10.1029/2002JD002053, 2003.

Volkamer, R., Baidar, S., Campos, T. L., Coburn, S., DiGangi, J. P., Dix, B., Eloranta, E. W., Koenig, T. K., Morley, B., Ortega, I., Pierce, B. R., Reeves, M., Sinreich, R., Wang, S., Zondlo, M. A., and Romashkin, P. A.: Aircraft measurements of BrO, $\mathrm{IO}$, glyoxal, $\mathrm{NO}_{2}, \mathrm{H}_{2} \mathrm{O}, \mathrm{O}_{2}-\mathrm{O}_{2}$ and aerosol extinction profiles in the tropics: comparison with aircraft-/ship-based in situ and lidar measurements, Atmos. Meas. Tech., 8, 2121-2148, doi:10.5194/amt-8-2121-2015, 2015.

Wozniak, A. S., Bauer, J. E., Dickhut, R. M., Xu, L., and McNichol, A. P.: Isotopic characterization of aerosol organic carbon components over the eastern United States, J. Geophys. Res., 117, D13303, doi:10.1029/2011JD017153, 2012.

Zhang, Y., Wang, Y., Gray, B. A., Gu, D., Mauldin, L., Cantrell, C., and Bandy, A.: Surface and free tropospheric sources of methanesulfonic acid over the tropical Pacific Ocean, Geophys. Res. Lett., 41, 5239-5245, doi:10.1002/2014GL060934, 2014.

Zhu, L., Nenes, A., Wine, P. H., and Nicovich, J. M.: Effects of aqueous organosulfur chemistry on particulate methanesulfonate to nonsea salt sulfate ratios in the marine atmosphere, J. Geophys. Res., 111, D05316, doi:10.1029/2009GL038465, 2006. 